\title{
Power in distribution channels: Supplier assortment strategy for balancing power
}

\author{
Jakob Rehme, Daniel Nordigården, Daniel Ellström and Daniel Chicksand
}

\section{Linköping University Post Print}

\section{Tweet}

N.B.: When citing this work, cite the original article.

Original Publication:

Jakob Rehme, Daniel Nordigården, Daniel Ellström and Daniel Chicksand, Power in distribution channels: Supplier assortment strategy for balancing power, 2015, Industrial Marketing Management.

http://dx.doi.org/10.1016/j.indmarman.2015.07.007

Copyright: Elsevier

\section{http://www.elsevier.com/}

Postprint available at: Linköping University Electronic Press

http://urn.kb.se/resolve?urn=urn:nbn:se:liu:diva-121505 


\title{
Power in Distributions Channels - Supplier Assortment Strategy for Balancing Power
}

\author{
Jakob Rehme $^{a}$, Daniel Nordigården ${ }^{a}$, Daniel Ellström $^{a}$, Daniel Chicksand ${ }^{b}$ \\ ${ }^{a}$ Division of Management and Engineering, Linköping University, SE-581 83 Linköping, Sweden \\ ${ }^{b}$ Aston Business School, UK
}

Jakob Rehme, Division of Management and Engineering, Linköping University, SE-581 83 Linköping, Sweden Linköping University, Sweden, e-mail: jakob.rehme@liu.se, tel.: +46 13 288447; fax: +46 131494 (corresponding author)

Daniel Nordigården, Division of Management and Engineering, Linköping University, SE-581 83 Linköping, Sweden, Linköping University, Sweden, e-mail: daniel.nordigarden@liu.se, tel.: +46 13 2882588; fax: +46 13 1494

Daniel Ellström, Division of Management and Engineering, Linköping University, SE-581 83 Linköping, Sweden, Linköping University, Sweden, e-mail: daniel.ellstrom@liu.se, tel.: +46 13 282480; fax: +46131494

Daniel Chicksand, Operations and Information Management Group, Aston Business School, UK, e-mail: d.chicksand@aston.ac.uk, tel.: +44(0)1212043361

Original submission: January 21, 2015

Resubmission: June 18, 2015

\section{Ref nr: 14-290RR}




\section{Authors' brief Biographical data}

Jakob Rehme is an Associate Professor in industrial economics and management. He received his $\mathrm{PhD}$ in industrial economics and management from The Institute of Technology at Linköping University, Sweden. His research interests include marketing and distribution channels as well as sales and purchasing management. He has published in international scholarly journals such as European Journal of Marketing, Journal of Business and Industrial Marketing, Supply Chain Management, and International Journal of Operations and Production Management as well as books and research reports. Prior to his academic profession he held various positions at $\mathrm{ABB}$ working with logistics, distribution strategies, sales and marketing, and project management.

Daniel Nordigården, $\mathrm{PhD}$, is Associate Professor of Industrial Marketing at Linköping University. Prior to his academic profession, Daniel spent over 5 years as a consultant supporting client teams and clients from over 20 countries. His current research deals with outsourcing, value creation, and value-added strategies.

Daniel Ellström is a $\mathrm{PhD}$ student at Linköping University and conducts his research within the field of industrial marketing. His primary research interest is retailer-supplier relationships and how suppliers can integrate in the category management of retailers.

Daniel Chicksand is a Senior Lecturer at Aston Business School. Before joining Aston he spent five years as a lecturer in Operations and Supply Management in the Operations Management group at Warwick Business School. He recieved his $\mathrm{PhD}$ at Birmingham University whilst working as a researcher within the Centre for Business Strategy and Procurement. His primary research interest is to better understanding how organisations can optimise their business relationships to create value. He has published book chapters and articles in leading academic and practitioner journals. He also runs a consultancy company with a focus on strategic sourcing, effective procurement techniques and process improvement. 


\section{Highlights:}

- Information asymmetry is an important power resource that can be used by suppliers to balance power

- Use of information asymmetry to change the power balance in a buyer-supplier relationship affects the two actors' ability to use coercive power

- Actions intended to change the power balance in a relationship can lead to more collaborative relationships

- For practitioners, we highlight the possibility to identify information asymmetries and use them to increase relative power 
Abstract - This paper focuses on the move from buyer dominance toward interdependence between buyers and suppliers in a distribution channel. The paper introduces a case study collected through in-depth interviews and participative observations. It examines the relationships between a timber supplier and its customers in the builders' merchants sector. We stress the relevance of considering actions intended to change the power balance, rather than focusing only on trust. The power balance in a dyadic relationship is dynamic, and power positions need to be constantly re-evaluated. An important power resource is information asymmetry, manifested in the supplier's information about: products, regional and local demand, and the usage of the products. For practitioners, we highlight the possibility of exerting a non-coercive power resource, such as information asymmetry, in order to increase the relative power. Furthermore, being open about the power position between a buyer and a seller can foster a more efficient collaboration.

Keywords - Power, distribution channels, information asymmetry, resource dependence, supplier-retailer relationships, assortment, power regimes 


\section{INTRODUCTION}

This paper explores the possibility for a supplier to change the power situation in a distribution channel by adjusting the amount of resource utility and scarcity brought to the table. Several researchers recognize the importance of understanding the power situation in terms of the dependency between buyer and supplier in a business relationship (e.g. Emerson, 1962; El-Ansary and Stern, 1972; Pfeffer and Salancik, 1978; Campbell and Cunningham, 1983; Provan and Gassenheimer, 1994; Frazier and Antia, 1995; Hingley, 2005; Caniëls and Gelderman, 2007). They often argue that the relative power is a result of the amount of utility and scarcity of resources that the buyer and seller respectively bring to a business exchange (also cf. Cox et al., 2000; Cox, 2007). A stronger power position is seen to enable a firm to appropriate more of the available value in a business relationship (Cox et al., 2004). The power position is consequently expected to be related to firm performance (e.g. Farris and Ailawadi, 1992; Ailawadi et al., 1995; Messinger and Narasimhan, 1995; Ailawadi, 2001). Others argue that the result of a power situation also induce non-financial changes, such as altering actors' behaviors (French and Raven, 1968; Wilkinson, 1996; Leonidou et al., 2008).

Assortment and its connection to power has received attention in literature about category captainship, where the control over assortment selection is discussed (Kurtuluş and Nakkas, 2011). Assortment management based on collaboration between suppliers and retailers has also been studied in literature about efficient consumer response (ECR), vendor managed inventories (VMI) and collaborative category management (e.g. Harris and McPartland, 1993; Dussart, 1998; Barratt and Oliveira, 2001; Kracklauer et al., 2001; Subramanian et al., 2010). One assumption is that suppliers have product knowledge and marketing responsibility, whereas retailers have an understanding of shopper behavior (Kracklauer et al., 2001). Moreover, the retailers are assumed to have control of assortment planning, pricing and in-store activities, generally having a stronger power position vis-à-vis their suppliers (Lindblom and Olkkonen, 2006). Other authors maintain that there are tendencies towards the outsourcing of category captainship to the suppliers, in effect altering the power balance in favor of the supplier (Kurtulus and Toktay, 2005; Kurtulus and Toktay, 2007).

This paper will address the effect of a move towards more supplier managed assortment and the resulting power balance between supplier and its merchants. This study focuses on a product category in a sector with limited market research and shopper behavior analysis. Instead, the store assortment has developed based on tradition and product availability. The empirical context is the relationship between a timber supplier and its customers in the builders' merchants (BMs) sector. The main purpose of this paper is to understand how supplier assortment strategies can affect the degree of dependence in a buyer-seller dyad, and how this can alter the power position therein.

This paper makes a contribution to the general field of industrial marketing research by increasing understanding of how power can be changed in a buyer-seller relationship. Few theories on power and dependence in buyer-supplier relationships address the question of how dependence can be used to change the relative power between two actors (some exeptions are Cox et al., 2003b; Cox et al., 2004; Chicksand, 2009). This paper extends the work on power regimes of Cox et al. (2000), with a particular focus on the movement from buyer dominance toward interdependence between buyer and supplier (cf. the power-regime framework defined by Cox et al., 2004). Explorations of power balance and its consequences for supplier-retailer relationships often describe power balance or imbalance at a certain point in time (e.g. Ailawadi et al., 1995; Hingley, 2005). Our study draws from this, but also considers the dynamic effects on the change in the power balance between a supplier and a retailer. It also uses the power-regime framework to reason about resource dependency (cf. 
Cox et al., 2003b; Cox et al., 2004) in the context of a market with commodity-type products when suppliers have difficulty increasing buyer dependence based on differentiating product utility. In this study we are looking at a situation where the supplier takes more responsibility over assortment management, and consequently how this changes the relative power between the actors. For practitioners, this paper highlights how managers could exert non-coercive power bases to increase a firm's relative power in a buyer-supplier dyad. Understanding how non-coercive power can be used helps managers in decision-making and in the analyses of negotiating situations.

\section{THEORETICAL BACKGROUND}

It is necessary to review the theories on power to understand how it can be used in a buyerseller relationship. In addition to the research about power conducted within the field of interorganizational relationships, this paper includes literature on the subject of power from disciplines such as sociology (Emerson, 1962; Cook and Emerson, 1978), behavioral science (Dahl, 1957; French and Raven, 1968) and economics (Bowles and Gintis, 1993; Ailawadi et al., 1995).

\subsection{Defining power}

There has been a long-lasting confusion concerning the definition of power, and an ambiguity in the interpretation of the power construct (Emerson, 1962; see also definitions by Dahl, 1957; French and Raven, 1968; Bowles and Gintis, 1993). Some researchers (e.g. Cook and Emerson, 1978; Gaski, 1984) refer to Dahl's definition of power as: A has power over $B$ to the extent that he can get $B$ to do something that $B$ would not otherwise do (Dahl, 1957, p. 202-203). French and Raven (1968) use influence and control to further define power. They describe influence as a force to change, induced by actor A on actor B. Influence is distinguished from control, because if $\mathrm{B}$ is exposed to a stronger force from another actor, $\mathrm{A}$ will not be able to control B. Power is defined as the maximum potential influence that A can induce upon B. French and Raven (1968) also stress that actor A often chooses to exert less than full power, meaning that the exerted influence is often less than the maximum.

Dahl's (1957) definition of power is also commonly used as a starting point in resourcedependence theory. Emerson (1962, p. 32) defines power as follows: The power of actor $A$ over actor $B$ is the amount of resistance on the part of $B$ which can be potentially overcome by $A$. Overcoming resistance is stronger than Dahl's definition of getting someone to do something they would not otherwise do, as it implies that B is unwilling to change. B might be willing to do something, but is unable to do so without the aid of A. In this case, no resistance is overcome, but A has still induced a change in B's behavior. While this would not be an exercise of power according to Emerson (1962), it would be so, according to French and Raven (1968).

In economics, the concept of power is primarily used to understand the share of value gained from a business relationship. Relative profitability is sometimes used as a substitute for relative power. Bowles and Gintis (1993, p. 88) defined power as: The ability of furthering one's interests by imposing (or credibly threatening to impose) sanctions on another agent when the converse is not also true. Therefore, when economists define the exercise of power as the imposition of sanctions, they imply the unwillingness of the influencee. The focus is on the effects, or the potential effects, of power in monetary terms.

For a distribution channel, El-Ansary and Stern (1972, p. 47) define the power of a channel member as: his ability to control his decision variables in the marketing strategy of another member in a given channel at a different level of distribution. This definition of power is also referenced by Hunt and Nevin (1974), Etgar (1976), and Gaski (1984). This perspective often 
connects the aspect of changing behavior with the aspect of value appropriation. A behavioral change is related to a company's decision variables, and the effects these decisions may have on the financial performance of the individual firm and the marketing channel. Based on the distinction between control and influence made by French and Raven (1968), the present paper defines power in a marketing channel as: the ability to influence the decision variables of another channel member. This definition of power is distinct from Emerson's, as it does not require resistance to be overcome when exercising power. Furthermore, the power balance between the buyer and supplier is based on power bases that result in behavioral change related to a business setting, and potentially has economic consequences.

French and Raven's (1968) definition of power bases is frequently used in the literature to differentiate types of power, although they are often referred to as 'power sources' rather than 'power bases'. French and Raven (1968, p. 263) define the five most common and important power bases: reward power, based on B's perception that $A$ has the ability to bestow rewards on him; coercive power, based on $B$ 's perception that $A$ has the ability to mete out punishments on him; legitimate power, based on the perception by $B$ that $A$ has a legitimate right to prescribe behavior for him; referent power, based on B's identification with A; and expert power, based on the perception that A has some special knowledge or expertise.

The quotation shows that the power bases mainly express B's perception of A's ability to influence them. Having a coercive power base does not mean that coercive power is used. In fact, it does not even say that coercive power can be used. It only says that B perceives A as able to use coercive power should they feel like doing so. An interesting case occurs when A can punish B, or has some special knowledge of which B is not aware. According to French and Raven (1968), this would not qualify as a power base. In one way, this makes sense, because as long as B is not aware of A's punishments, rewards, legitimacy, or knowledge, A cannot influence B's decision variables. However, as soon as the punishment is dealt or the knowledge is revealed, B will be aware of A's power to influence their decision variables. Thus, the power base will come into existence.

\subsection{Power and dependence}

In distribution-channel power literature, efforts to operationalize dependence have used different indicators of the attractiveness and availability of resources (see e.g. El-Ansary and Stern, 1972; Etgar, 1976; Provan and Gassenheimer, 1994). The indicators often measure the percentage of a channel member's business that is placed with another channel member, indicating the utility (or the attractiveness) of the resources, and the difficulty of replacing a channel member, indicating the scarcity (or the availability) of the resources. We use the terms utility and scarcity to describe the constructs of dependence.

It is important to distinguish between relative dependence and one actor's dependence on another actor. Ramsay (1994) defines power in a buyer-supplier relationship as the ability to modify purchase or product specifications, which implies that power is used for bargaining a contract. Since Ramsay defines power as being determined by the interdependence between the buyer and seller, power becomes a zero-sum game, in which one actor's power gain means the other actor loses power. Other commentators (e.g. Emerson, 1962; Gaski, 1984; Bacharach and Lawler, 1986) do not define power as a zero-sum game. An actor's power in this case is determined by the dependence of the counterpart. In a buyer-seller relationship, the buyer's power and the seller's power are independent of each other. One actor's power gain does not mean the other actor loses power. This definition of power and dependence not only makes it possible to describe power imbalances, but also to distinguish interdependence from independence. 
In addition to the distinction between mutual dependence and mutual independence, power is not a force that affects all areas of the relationship between two channel partners in the same way. French and Raven (1968) claim that power has a range, which means that it can only be exerted in an area where the channel partner is dependent on the power holder. Kaplan (1964) similarly writes about the scope of power. Power and dependence should, therefore, be treated as issue-specific (Lusch and Ross, 1985).

\subsubsection{Power and dependence dynamics}

The desire of firms to maintain autonomy has led authors to claim that firms become involved in inter-organizational relationships only when they are compelled to do so (Van de Ven and Walker, 1984). However, firms do not have the necessary resources to manage all activities within their own organization (Cook, 1977). Firms must engage in relationships with other organizations in order to obtain these resources. In other words, the firm's resource dependency leads to the relationship (cf. Aiken and Hage, 1968; Pfeffer and Salancik, 1978). Following the same logic, for the counterpart in the relationship to engage, firms must also have a degree of dependence on resources, such as financial incentives. Therefore, there exists a degree of mutual interest in the buyer-supplier business relationship. Although this might be the case, individual firms will usually try to influence the terms of the relationships to obtain as much benefit to themselves as possible (Rumelt, 1987). Cox (2007) argues that, in order to affect the counterpart's behavior in a buyer-seller relationship, it is necessary to have more control over the available resources vis-à-vis the other party. Consequently, such situations involve a power imbalance between buyer and seller, in which one party is more dependent on its counterpart than the other (Emerson, 1962; Blau, 1964; Cook, 1977; Cook and Emerson, 1978).

Inspired by economic theory, management scholars make a connection between power and profitability for actors in a distribution channel (Galbraith and Stiles, 1983; Ailawadi et al., 1995; Cook and Henderson, 1998; Collins, 2002). Increasing market power enables an actor to increase relative profitability. Therefore, using a strategy to change a relative power position will lead to a change in value appropriation between the buyer and the seller.

In economic literature, current share of profitability is associated with exercised power (Ailawadi et al., 1995). This is based on the logic that exercising power means that changes are made in the buyer-seller relationship, which increases the influencer's share of the profit. Using this reasoning, neither dependence nor power bases create changes in relative profitability unless they are used to exercise power.

\subsubsection{The power-regime framework}

Cox (1999) and Cox et al. (2000) developed a matrix, which Chicksand (2009) further developed (Figure 1), for dyadic relationships that fall under four basic power positions: supplier dominance $(<)$; buyer dominance $(>)$; interdependence $(=)$; and independence $(0)$. In a situation of buyer or supplier dominance, either party has control over a larger share of the available resources compared with their counterpart. Non-adversarial collaboration between the buyer and the supplier most likely occurs in an interdependent power situation (Cox et al., 2004). 


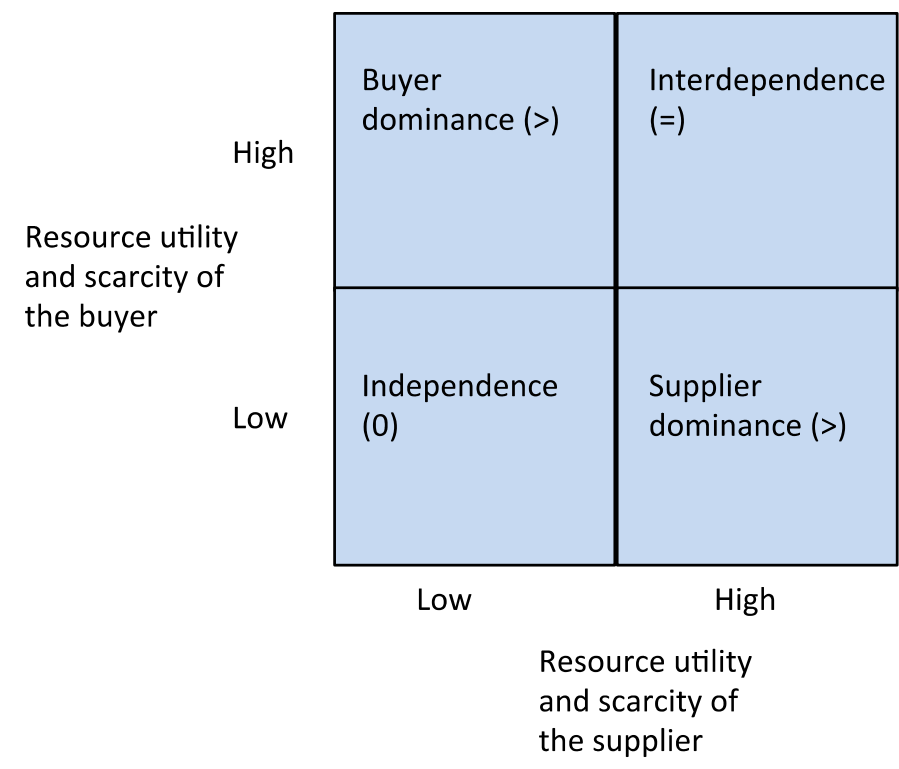

Figure 1: Power-regime framework (adapted from Chicksand, 2009)

\subsubsection{Information asymmetry}

Drawing on the power-regime framework of Chicksand (2009), Cox (1999; 2007), and Cox et al. $(2000 ; 2003 ; 2004)$, this paper distinguishes determinants of relative power in market scarcity and resource utility in buyer-seller relationships. Information asymmetry (Cox, 2001; Lonsdale, 2005) is one important resource that has received very little attention in resourcedependency literature (Cox, 2001). Information asymmetry is related to the amount of private and general information available to each party concerning the transaction itself, and the objectives of the other party in the exchange. This asymmetry is the balance of private information - financial liquidity, budgets, cost and reservation price, what is valued, who specifies what, and so on - and other general industry information - on competitors, upcoming technologies, industry insights, and so on - between two parties in a business relationship (Cox, 2001; Cox et al., 2003a). Information asymmetry, and the resulting resource scarcity or utility, can result in opportunistic exploitation of superior knowledge (Cox, 2001). From an opportunistic perspective, one party can use the advantage of knowledge to manipulate or distort their counterpart's perceptions of the range of potential alternatives ex-ante (cf. Akerlof, 1970), or shirk or cheat when exercising the contract (Cox et al., 2003a).

\subsection{Synthesis of theoretical background}

Scarcity of resources within an individual firm has been argued to cause it to interact with others (Aiken and Hage, 1968; Pfeffer and Salancik, 1978). Difficulty in obtaining resources from other firms depends on market availability (El-Ansary and Stern, 1972; Etgar, 1976; Provan and Gassenheimer, 1994; Cox, 2007). In other words, the number of suppliers that can provide those resources provides a measure, or indicator, of market scarcity. Consequently, a buyer experiences high market scarcity when there are only a few available suppliers with the required resources. In marketing terms, strategies that result in supplier market scarcity, often referred to as positioning and differentiation (cf. Porter, 1980), create isolated market mechanisms (Teece, 1986). The other aspect of power determinants is from a utility perspective, in which the amount of information or know-how that one party possesses 
can affect the other party's dependence on the information-holder (cf. French and Raven, 1968).

The power balance between buyer and seller can be affected by changes in the power determinants. For instance, introducing a high-utility product could create a new marketscarcity situation. The power situation as defined by French and Raven (1968), whereby the buyer or seller can affect the power bases, is dynamic. Because of the difficulty in differentiating between the variants of non-coercive power bases, we use a simplified version, in which the power bases are defined as either coercive or non-coercive (e.g., Hunt and Nevin, 1974; Lusch and Brown, 1982). Coercive power is described as 'punishment', while non-coercive power is described as 'assistance' (Lusch and Brown, 1982). This punishment or assistance is often measured from the perception of the influencee (French and Raven, 1968).

\section{METHODOLOGY}

This study explores the possibility for changes in the power balance of a distribution channel. Although power in distributions channel is a relatively well-researched topic, to our knowledge little has been written about these dynamic changes in power positions in distribution channels. Since power is a complex construct that is difficult to objectively measure, and since it is our view that determinants of power are multi-faceted, there is a need for an in-depth understanding of the practices among the involved actors (Eisenhardt, 1989). Due to the explorative nature of this study, and the need for an in-depth understanding, a qualitative case-study approach is suitable (Miles and Huberman, 1984; Eisenhardt, 1989; Yin, 2009; Piekkari et al., 2010). This allows us to capture a nuanced view of the changes in power positions among the actors in a distribution channel. Some commentators have criticized the exploration of a phenomenon through in-depth case studies, citing the inherent difficulties in generalizing, but it can also be an opportunity to understand interaction between a phenomenon and its context, such as the power balance between two actors (Dubois and Gadde, 2002). We consider case studies to be a suitable method of data collection, since an aim of this research is to discover emerging patterns and practices (Meredith, 1998).

\subsection{Research Design}

The case studied in this paper is the distribution channel through which TimberSupplier supplies builders' merchants (BMs) in the UK with moldings and planed timber products (Figure 2). TimberSupplier is an importer, manufacturer, and distributor of timber products based in the UK. We examined power dynamics between TimberSupplier and BMs in a dyadic exchange relationship. The case includes several buyer-supplier relationships, which are part of the same distribution channel and share the same supplier.

Adopting a qualitative case study approach was suitable as it was necessary to conduct indepth research to capture complex, often socially embedded power dynamics (Miles \& Huberman, 1994; Eisenhardt \& Graebner, 2007; Yin, 2003). A combination of methods was used, including participant observations and semi-structured interviews with key individuals (Shah \& Corley, 2006). Drawing generalizations from a single case can be problematic, as it is difficult to determine how case specific the findings are. To compensate for this and increase generalizability, the findings in this paper are compared with previously developed theory. This has been referred to as analytical generalizability (Meyer, 2001; Yin, 2009) and 
is recommended for single case studies. The reasons and justifications for choosing this case study began with the selection of the supplier, and then the selection of the BMs.

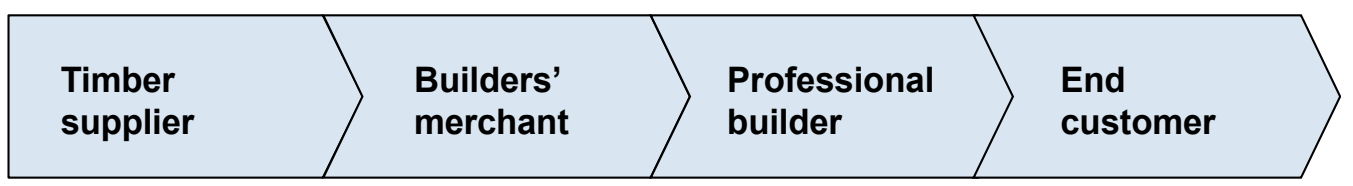

Figure 2: Visualization of the distribution channel used as the case in this paper.

\subsubsection{Timber supplier}

TimberSupplier was chosen for this case study as it provided the ideal setting to explore the phenomenon of power in buyer-seller relationships. Additionally, TimberSupplier provided important data accessibility and connections to BMs and other key players within the distribution channel. TimberSupplier initiated this research project as part of its attempt to improve cost efficiency in the supply chain. By employing one of the authors of this article as an industrial PhD student, the company gave the project a high priority, which allowed us access to a large amount of data within the company. The practical challenges experienced by the actors studied mainly concerned the assortment management of the BMs. The BMs did not perceive that their familiarity with TimberSupplier's products and supply chain were sufficient to be extensively used in their assortment management. From a theoretical perspective, this paper applies theories of power and dependence in order to understand these inefficiencies. TimberSupplier provides a good example of a supplier that is interested in balancing power in relation to its customers. The added fact that TimberSupplier operates in a stable market enabled us to study the company and its situation over an extended period of time without any major changes occurring.

Saunders et al. (2007) describe several ways of selecting samples for a data set. Following this classification, we use a combination of purposive selection, self-selection, and convenience selection in this paper. The intent of the purposive selection is to select a typical case of a supplier that is interested in balancing its power position.

\subsubsection{Builders' merchants}

Having decided on TimberSupplier as the studied supplier, the BMs were selected from its customers or potential customers. The choice of which BMs to incorporate was not made beforehand, and the researchers determined the criteria to decide which ones should be approached for the case study.

While looking for BMs to incorporate into the study, we used an active sampling method to identify customers that suited the research purpose. Purposive selection (c.f. Saunders et al., 2007) was used to capture typical, yet heterogenous, cases from the group of TimberSupplier's customers. From the available BMs, we selected the three national merchants to which TimberSupplier supplies its products as the main focus in the case. In addition to the national merchants, in order to provide a broader view of the market, we also included a number of independent BMs that are members of a buying group. It is important to consider the buying groups in order to understand the power relationship between the supplier and the BMs. In the sampling of chains and independent BMs, support was provided by TimberSupplier managers, who offered deeper insights into how the BMs differed from each other, and which BMs would be suitable to include in the study. 
Retailer sampling was not carried out as a separate stage, but as a continuous process (c.f. Dubois and Gadde, 2002). As the project evolved, the interest in different types of retailer shifted. Larger chains were targeted initially, but as an interest in understanding the relationships with smaller BMs increased, the need to involve independent BMs became evident.

\subsection{Data collection process}

Data collection was carried out during six visits to the UK. The duration of the visits ranged from two days to two weeks. Data was collected through participative observations and interviews. The participation and interviews mainly occurred simultaneously, but are described separately.

\subsubsection{Interviews}

The traditional method of conducting case research within industrial marketing is by interviews (Easton, 2010). In the initial stages of the research project, we saw a need to learn what the involved companies were doing and what their relationships looked like. The interview method was appropriate for obtaining this basic understanding.

The interviews took place in parallel with, and sometimes as part of, the observations. Fortyfive interviews were conducted. All interviews were held with employees, either those of TimberSupplier or those from BMs. Seven interviews conducted with top TimberSupplier managers and national BMs' central management largely shaped the project and its results. These seven key interviews were recorded and transcribed. Findings from these interviews provided the basis for determining the scope of the research, and the focus of the remaining data collection.

The remaining 38 interviews were informal, and included open-ended questions. During these interviews, we took notes and wrote down key quotations. After the interviews, we made descriptive summaries of what had been said. The informal nature of the interviews provided us with opportunities to receive continuous feedback on the preliminary results, thus increasing their validity (Eisenhart and Graebner, 2007; Yin, 2009). Table 1 shows the distribution of all interviews. The respondents included people in positions ranging from senior management to regular staff. Both large and small BMs were visited, as well as independent BMs and branches that were part of a chain. This provided us with a broad view of the distribution channel.

Table 1: Interviews with various actors

\begin{tabular}{|c|c|c|}
\hline & $\begin{array}{l}\text { Number of } \\
\text { Interviews }\end{array}$ & Main Focus of Interviews \\
\hline $\begin{array}{l}\text { TimberSupplier Top Managers and } \\
\text { Directors }\end{array}$ & 13 & $\begin{array}{l}\text { General business setting and } \\
\text { power position }\end{array}$ \\
\hline $\begin{array}{l}\text { TimberSupplier Account Managers, } \\
\text { Sales etc. }\end{array}$ & 11 & Potential power and change \\
\hline National BMs - Central Management & 4 & $\begin{array}{l}\text { General business setting and } \\
\text { power position }\end{array}$ \\
\hline National BMs - Branch Management & 12 & Potential power and change \\
\hline $\begin{array}{l}\text { Independent BMs - Members of a } \\
\text { Buying Group }\end{array}$ & 5 & Potential power and change \\
\hline
\end{tabular}




\subsubsection{Participative observation}

Following the recommendation of Piekkari et al. (2010) to use different sources of data in case studies, we did not limit this study to interviews. We found that participative observation provided a valuable complement to the interviews. Close collaboration with the studied timber supplier enabled successful participative observation. We spent fifteen days visiting 22 BM branches, often accompanied by TimberSupplier account managers. We observed account managers, employees in the BM branches, and the interactions between these people.

Between BM branch visits, we spent numerous hours traveling with the account managers. During these times, we gained insights into their daily routines and observed their telephone conversations with customers and colleagues.

We took notes during and after the observations. The notes included direct quotations, which were mainly made during the observations, and descriptive summaries of the events, which were mostly made after the observations.

During all such participations, a recurring theme of the initiated discussions related to range and assortment. For example, we discussed opinions on, reasons for, and challenges presented by the current assortment, as well as possible solutions to these challenges. The decisions about what products to sell in BMs are a central part of the relationship between timber suppliers and BMs. Therefore, many of the quotations relate to the assortment of BMs, and decisions on which products to sell.

Participative observation has several benefits as a data-collection method. Firstly, access is given to information that would otherwise have been inaccessible (Yin, 2009; Justensen and Mik-Meyer, 2011). One finding from the initial interviews was that respondents were either reluctant or unable to describe the processes and the logic behind decisions on how to conduct business. By being present during discussions between the buyer and the supplier, we were able to observe how decisions were made. Access to supplier databases also enabled a better understanding of the situation. Secondly, participative observation allowed us to manipulate events in a desired manner (Yin, 2009). We were able to arrange meetings, and to steer the development of the project, in order to focus on critical areas. Thirdly, it allowed us to analyze the impact of the context (Justensen and Mik-Meyer, 2011). By understanding the unique characteristics of the timber trade, we distinguished between context-specific and general conclusions. Finally, participative observation stimulates creativity by discovering new findings in the field (Justensen and Mik-Meyer, 2011).

However, there are also certain difficulties associated with participative observation. It can create bias, as the researcher might get too close to the organization and become a supporter of its conduct (Yin, 2009). However, the fact that the purpose of the research is to explore problems experienced by a specific company limits the risk of bias. If the purpose had been to seek opinions on the company's current way of doing business, this risk might have been greater. A second difficulty with participative observation is that the researcher might spend too much time participating and too little time observing, and hence may be unable to find enough time to take notes and ask the questions that the observer role requires (Yin, 2009). Although we did allocate time to ask questions, the notes taken during the participations were sometimes not extensive enough. We felt that if we spent too much time writing down what was said, then this would impede the flow of the discussions. Participants might become restricted in what they said when they felt as if they were being formally interviewed. By writing down only what we considered to be the most important facts, we felt the discussions ran more efficiently. 


\subsection{Data analysis}

Data collected in our study was analyzed through a pattern matching technique (cf. Yin, 2009) and organized around topics (cf. Hartley, 2004) corresponding to the three subsections in the findings (determinants of power, ability to influence and dynamic change of power position). An initial division was made between data describing how business traditionally is conducted, i.e. determinants of power create and ability to influence, and data regarding business development and change, i.e. dynamic change of power position. This is based on the assumption that determinants of power create an ability to influence, that in turn lead to a change in power position. Thus, the coding of data was made to capture the traditional determinants of power, the traditional ability to influence activities and the developing changes in power positions in the relationship.

During participation and informal interviews, we collected a large amount of data that contributed to our understanding of the context, even though it did not provide direct answers to the formulated research questions (cf. Savage, 2000). Consequently, we considered much of the gathered material not directly related to the three subsections in the findings, and we excluded it from the analysis. The data related to each subsection was analyzed to identify patterns (cf. Yin, 2009). These patterns provided the basic building blocks for the findings, where they are all accounted for under the three subsections (eight patterns in total).

\section{EMPIRICAL STUDY}

The marketing channel of TimberSupplier's timber products sold in the UK includes three sets of actors: TimberSupplier, the BMs, and the customers buying from the BMs. The BMs targeted in this study are three of the national BMs and three buying groups present on the UK market. The different kinds of BMs are further described in Section 4.2.

As with other retail sectors (c.f. Messinger and Narasimhan, 1995), BMs have become increasingly consolidated (Henningsson, 2005; Ellström, 2013; Guan, 2013) and, arguably, have created a stronger power position in relation to their suppliers. This especially applies to those commodity products supplied by TimberSupplier: low-margin products that do not carry strong brand names (cf. Rehme et al., 2013). For BMs that buy wood products, there are usually alternative suppliers to TimberSupplier that offer comparable or substitutable products. As a complicating factor, BMs sometimes have their own planing facilities for finishing wood material into final products. This makes them competitors to their own suppliers, thus controlling scarcity and/or utility. Professional builders and end-customers are fairly independent of the BMs since they can always find an alternative building material supplier. Similarly, BMs do not normally rely on customers and end-consumers, given the high number of customers/builders and potential end-consumers on the market.

\subsection{The supplier}

TimberSupplier controls a large part of the supply chain, starting from the nurseries in which saplings are grown, to the forests, the sawmills, and the machining of the timber into finished products, right through to product distribution to the BMs. This makes TimberSupplier knowledgeable about the characteristics of the sold products, and increases its reliability and trustworthiness as a knowledgeable timber supplier.

According to TimberSupplier's managing director, the company holds a vast number of stock keeping units (SKUs), which results in inefficiencies. One reason for the ill-considered nature of TimberSupplier's range management is its lack of knowledge about its customers' 
businesses. Although account managers spend considerable time with the BMs, they do not perceive themselves as fully understanding of the BM business, or the customers of BMs.

\subsection{The builders' merchants}

The BMs are a heterogeneous group of companies that vary greatly in the ways they run their businesses. In this study, both national merchants and buying groups that organize independent BMs are included. The national merchants are large companies with a nationwide presence. Members of buying groups are independent merchants that have joined a buying consortium that takes responsibility for negotiating with suppliers. The members of the buying groups are then allowed to purchase products at prices negotiated by the buying group. These independent merchants can have one or several branches, but do not have nationwide presence and perceive themselves to be too small to negotiate their own contracts with suppliers. Joining a buying group increases the independent merchant's purchasing power relative to the supplier, but it also makes them dependent on the buying group.

There is an ongoing trend for consolidation within the industry, which is driven by the need to cut costs (Agapiou et al., 1998; Nord, 2005). However, many independent branches are owned by the branch manager operating the business, and they are often reluctant to sell their businesses to a national brand. Therefore, many independent merchants still remain.

Because timber products are low value products, it is not economically feasible to place single orders of products unavailable in a branch. The choice of what assortment to use in the branches is therefore a critical one. The product assortment kept in BM branches is usually determined by the branch managers. However, BM chains must follow guidelines from central management. One reason why BM chains often give branches control over which assortment to keep relates to the knowledge branches possess regarding regional requirements, which all actors consider to be very important. In selecting an assortment, branches are highly influenced by nearby competitors and what has historically been used in that region. The main downside of letting BM branches select their own assortment is believed to be related to their limited knowledge about the effect their assortments will have on the entire distribution channel. This means they risk selling products that decrease distribution channel efficiency.

\subsection{Customers}

In the BM distribution channel, the customer is usually a joiner or some other kind of builder. When builders were asked to explain their motivation for selecting a certain BM branch for their purchases, they provided several reasons. The most common reasons related to proximity, familiarity, service, BM staff expertise, product assortment and quality, and price. Depending on how builders evaluate the above factors, they may find some chains or branches more appealing than others. Whereas some branches try to differentiate themselves by having fair prices, others will differentiate themselves by having a wide assortment of products, or by employing competent staff.

\section{FINDINGS}

Our study provides several indications of the current power balance between the supplier and the BMs, and how suppliers can potentially change this power balance. From the case study, it is evident that TimberSupplier greatly depends on BMs. In addition, the findings also suggest that the BMs are independent of TimberSupplier. This creates a situation of buyer dominance. However, with TimberSupplier's strategy of taking more responsibility for 
assortments stocked by BMs, it is possible to see a development toward BMs depending more on TimberSupplier, leading to interdependence between the actors.

\subsection{Determinants of power}

In this study, we have identified three main determinants of power: supplier's lack of expertise about costs and demand; the fact that buyers can utilize expertise from other sources; and buyer purchasing clout.

\subsubsection{Supplier lacks expertise about costs and demand for their products}

One way of increasing BMs' dependence on TimberSupplier is for the supplier to provide BMs with useful knowledge about costs and demand for their products. This is not currently the case, because TimberSupplier lacks this expertise. This shows a lack of power base in TimberSupplier. According to Brown et al. (1983), a firm's lack of expert power indicates low dependence on that firm.

The calculated role costs in our system are not up to date. Account manager, TimberSupplier.

The role costs in TimberSupplier are meant to indicate the actual costs for producing and distributing the products provided to BMs. However, the calculations used to determine role costs are based on how production and distribution were carried out historically rather than currently. In addition, the role costs do not consider machinery switching costs that, for lowvolume products, constitute a considerable portion of the total costs. When switching costs are not considered, the benefits of creating a smaller range of faster-selling products are not visible. A buying manager noted the lack of customer knowledge:

TimberSupplier and their competitors don't talk to our customers, and that's a shame. Timber buying manager, BM1.

TimberSupplier is largely unaware of how customers making purchases from BMs use TimberSupplier products. The Managing director at TimberSupplier noted:

When we negotiate with BMs, they just say that they order the products that are demanded by the builders and we cannot argue against them because we simply do not know. Managing Director, TimberSupplier.

Even though TimberSupplier can use its sales data to determine the demand for products, they lack the qualitative understanding of how the products are used, which makes it more difficult to interpret the sales data.

\subsubsection{Buyers can utilize expertise from other sources}

BMs can choose from several suppliers. Because suppliers have very similar offerings, BMs let price levels determine who will make the sale. When BMs let suppliers compete solely on the basis of price, BMs do not depend on the competence of any one supplier.

The BMs' Buying Groups generally have three main suppliers for moldings and then the individual branches can choose whom to supply from. Sales director BM, TimberSupplier.

The independent BMs that are part of a buying group use supplier contracts established between the suppliers and the buying group. The buying groups usually create contracts stating delivery conditions and price levels for products, and the BMs are then free to select among those suppliers. For commodities, such as timber products supplied by TimberSupplier, pricing is an important factor in determining who will make the sale: 
If TimberSupplier does not accept the price requested by independent BMs, they will ask some other supplier. This supplier will then also get the opportunity to deliver other products as well. Account manager, TimberSupplier.

The buyer also expressed a focus on price:

Data on supplier prices are updated every month on the BM2 intranet, and should be used to determine the cheapest supplier and use that one. Purchasing and sales manager in local branch, BM2.

The focus on price is even a basis for categorizing suppliers:

We have three kinds of suppliers, based on the rebates we receive. Priority suppliers are the ones where BM2 gets lots of rebates. Branch manager, BM2.

Among independent BMs and BM chains, pricing is the most important decision factor in the choice of supplier. This importance of pricing indicates that BMs currently do not depend on the expertise of any one supplier.

\subsubsection{Large purchasing clout of the buyer (financial)}

Due to the size of the BMs, every contract with a BM is important for TimberSupplier. If TimberSupplier loses a contract with a current customer, it is devastating for business. If it is able to win a contract from a competitor, this is positive for TimberSupplier's turnover, but also means that it has probably negotiated away most of the profits from the deal. In power literature, the connection between a firm's size and the dependence of other companies on that firm is not contentious. The size of firms is often an indicator of power or dependence (Wilkinson and Kipnis, 1978; Galbraith and Stiles, 1983; Provan and Gassenheimer, 1994), which is strongly felt by the selling department at TimberSupplier:

Almost all BMs are part of a powerful buying group or are powerful in themselves, because of their size. Sales director BM, TimberSupplier.

The buyers also discussed purchasing clout and buying power based on the size of purchase:

The buying groups create buying power through the volumes they buy.

Branch timber manager, BM4.

Both TimberSupplier and BMs make a connection between the size of a BM chain or buying group and their power. TimberSupplier depends on the BMs, as the large volumes sold to each BM chain or buying group constitute an important part of the supplier's turnover.

\subsection{The ability to influence activities}

The study identified two indicators of TimberSupplier's dependence on BMs: how BMs place demands on TimberSupplier, and the fact that BMs can minimize TimberSupplier's profit margins. These indicate that TimberSupplier currently depends on BMs.

\subsubsection{Buyer can place demands on supplier and its offerings}

Another indicator of TimberSupplier's dependence on BMs is the demands BMs place on TimberSupplier, which strives to live up to these demands. This indicates that the company values its relationships with BMs. If TimberSupplier were to be independent of BMs, the demands that the latter placed on the former could lead to TimberSupplier abandoning the relationship. In the studied case, the BMs perceived this risk to be minimal. Instead, they are able to make specific financial demands on their suppliers: 
I sit down with suppliers and discuss what they can do for us...from a return-of-capital point of view. Group negotiator timber, BM3.

Similarly, TimberSupplier expresses:

BM3 is saying that we have to bring an interesting offering to the table. $\mathrm{BM}$ sales manager, TimberSupplier.

In their negotiations with TimberSupplier, the BMs require the supplier to come up with an interesting offering. A supplier must create something special if they are to be the one selected. As few suppliers can create an offering that differs greatly from those of their competitors, they must instead offer lower prices.

\subsubsection{Buyers are able to put pressure on the margin of the supplier}

The BMs are capable of keeping TimberSupplier's margins down by negotiating the prices of the products they buy. As long as the offering from TimberSupplier is essentially the same as that of its competitors, the availability of the firm's resources is a high priority for the BMs (c.f. Emerson, 1962; Brown et al., 1983). This makes it difficult for TimberSupplier to achieve above-average returns (c.f. Cox and Chicksand, 2007). In the situation of buyer dominance, a supplier is constantly forced to be innovative and to make changes for the benefit of the buyer without achieving above-normal returns (Cox and Chicksand, 2007):

BMI's strategy is about retaining margin, and taking value away from the supplier and keeping all the difference. Group negotiator timber, BM3.

This view is shared by the supplier:

If we are able to reduce our total costs, the BMs would want to have a part of this...If we reduced costs by changing our range, our customers would demand a reduced price, at least if we are not capable of increasing their sales by our suggested range. BM sales manager, TimberSupplier.

Reducing costs at TimberSupplier would lead to BMs demanding reduced prices. BMs can ensure that some of the value created by suppliers falls into their pockets. Due to TimberSupplier's dependence on the BMs, it lacks the power to retain all value from its cost reductions. Thus, the BMs' ability to demand price reductions from TimberSupplier indicates that TimberSupplier is dependent on the BMs.

\subsection{Dynamic change of power position}

TimberSupplier's market expertise increases the dependence of BMs on TimberSupplier. TimberSupplier also has unexploited resources, such as expertise and financial resources, that can further increase the BMs' dependence on the supplier. The BMs also demand that TimberSupplier make implementations, and take steps to increase its responsibility in a way that would further increase the BMs' dependence on TimberSupplier. Taken together, these current and possible future developments provide insights into how suppliers can balance their power relative to retailers.

\subsubsection{Buyers are becoming dependent on the market expertise of suppliers}

Some BMs are already beginning to appreciate the potential benefits of using TimberSupplier's market expertise. By listening to suppliers and adapting to what they recommend, BMs are becoming increasingly dependent on their suppliers.

BMs provide products from many other categories besides timber products. Depending on the history of a BM branch, its knowledge of timber products can vary. Some branches are, or have previously been, solely timber merchants selling wood products. In that case, the branch 
manager is likely to be knowledgeable about the products offered by TimberSupplier. In other cases, such as BMs that were originally ironmongers and have expanded to become full service BMs, they are less interested and knowledgeable in timber products. The branch's timber knowledge is then likely to be low:

Some branches don't focus on timber and have little knowledge of what they sell. Account manager, TimberSupplier.

BMs with little understanding of timber products must rely on a timber supplier's knowledge if they are to create a competitive offering:

I think BM2 likes TimberSupplier because of the company's new product development skills and the marketing aid they provide to us. Branch manager, BM2.

The knowledge demanded is often related to end-consumer development:

For example, we can ask a supplier to describe a certain part of the country's market. Which are the growing products? Which are the decreasing products? Are we over- or under-performing? Group negotiator timber, BM3.

The seller is trying to take advantage of the available knowledge and information regarding products and markets:

Over the past three years that I have been involved with BM3, we've taken out and we have made the base bigger, and we have talked them into stocking other products that are faster moving and easier for us to produce in large volumes. And that has worked. I've got to say that has worked. Regional sales manager, TimberSupplier.

Regardless of the BMs' experience and knowledge in timber products, they may still need TimberSupplier's help familiarizing themselves with the products TimberSupplier supplies. The quotations provide several examples of how TimberSupplier can aid BMs. The help required by BMs ranges from trend analysis, to suggestions for assortment changes, to more hands-on marketing aid in the form of information about the different products. Store layout advice and sales promotion aids were mentioned as examples of the expert power of the supplier in supplier-retailer relationships (Brown et al., 1983). As most BMs lack the expertise to perform these activities and produce this information themselves, they depend on the expert power of TimberSupplier.

\subsubsection{The supplier has unexploited resources in terms of expertise and financial resources}

If TimberSupplier's resources were better exploited, the BMs' dependence on TimberSupplier could be increased. As the quotations reveal, TimberSupplier has both the expertise and the financial resources that BMs require, but it is not using these resources to their fullest extent in the relationships with its customers:

Sometimes we know our customers' demands; we then want to help with how to deliver to them in the most efficient way. You know, the sawmills and forests and all the technical aspects. What to put in the stores is a two-way decision. Buying manager timber, BM1.

This quotation refers to demands on TimberSupplier to use its expertise regarding the costs appearing in the distribution channel, and to help the BM decide which products to sell. The assortments offered in the stores influence the efficiency of the distribution channel. BM1 sees the potential of making TimberSupplier more involved in deciding which assortment to 
use in its stores. This is because the supplier knows everything that happens to the product prior to its placement on the store shelves:

TimberSupplier might come up with a new product, but before there are any sales on it you want BM1 to commit by putting half a million pounds of stock at risk... Where you get smart is saying something like: "Help me put my products in front of our customers, I will work with you to manage that and exit it if it doesn't work. " Buying manager timber, BM1.

This setup resembles the slotting fees charged by several types of retailer as advance payments for agreeing to stock new products (Sullivan, 1997). From the research, slotting fees are seen as a way of improving distribution efficiency (Bloom et al., 2000; Sudhir and Rao, 2006; Foros et al., 2009), but also as a way for large retailers to abuse their power by forcing risk upon the manufacturers (Bloom et al., 2000; Shaffer, 2005; Foros and Jarle Kind, 2008). In this case, TimberSupplier has a clear incentive to replace low-volume products with more cost efficient ones. As TimberSupplier has greater knowledge than BMs about the demand for all the products in TimberSupplier's product range, they are also able to contribute to the assortment management of the BMs. TimberSupplier can, therefore, voluntarily bear the risk in order to gain more control over the BM assortments. When TimberSupplier makes suggestions on changes to the assortment offered by a BM, the branch manager is often reluctant to devote store space and invest in buying new products, particularly if it adds to the existing product range.

If TimberSupplier was instead willing to take responsibility and guide the decision making for an appropriate total assortment in an individual BM branch, then there would be a higher likelihood of the BM accepting this suggestion. In this case, a BM would also depend more on TimberSupplier and its financial resources when reviewing its assortments. In the studied case, the timber supplier's increased risk is, therefore, a means to improve distribution efficiency.

5.3.3 The demand for further action related to an increase in buyers' dependence on the supplier

We identified a demand for TimberSupplier to take further action, mainly in discussions with BMs. These actions to develop the business relationship of the dyad, would contribute to increasing the dependence of BMs on TimberSupplier. They are important in order to explore possible supplier strategies for balancing power. The respondents see a need for TimberSupplier to increase collaboration, to share its expert power, and to familiarize itself with its customers.

If we concentrate on those suppliers we agree with, that's where we can have very successful changes of the business. We are trying to get there, but we are not there yet. We need to get the entire supply chain working as one organization in order to get the most possible profit... In today's market, with uncertainty about the future and carbon footprint hype, timber sales would skyrocket, but they don't, because the timber market doesn't work together. We don't interchange technology and don't benefit from each other. Group negotiator timber, BM3.

The demands to increase collaboration in the supply chain require TimberSupplier to take responsibility for making decisions that the company is not used to making. In particular, TimberSupplier must participate more in the businesses of the BMs and provide guidance in areas such as making decisions on what products the BMs should stock, and how they should market them: 
I am concerned with sales and margin. Suppliers helping out with this are appreciated. Branch manager, BM2.

This also extends to the internal organization of BMs and their branches:

The guys working in the BM counter can't know all the products of their suppliers. You have to help them, by showing what's possible...Can we come to a level where TimberSupplier suggests an order to us and comanage this inventory? Not only coming down to price, but stock weeks, etc., showing the value. Group negotiator timber, BM3.

BMs also demand that TimberSupplier use its expert power to further improve the offering in the BM branches. The above quotations describe the BMs' demands for expertise, but do not indicate if TimberSupplier currently has this expertise. To support the BMs in their operations, it is likely that TimberSupplier will need to increase its competence regarding the demand for products and value creation. This competence can then provide an expert power base and increase the BMs' dependence on TimberSupplier:

TimberSupplier needs to be better at understanding the end customers' wants and be able to show the impact of changes. Key account manager, TimberSupplier.

The following quotation from the seller also highlights the need to better understand the market and the individual customer:

TimberSupplier in general needs to be more proactive than reactive and become closer to customers. Sales director BM, TimberSupplier.

TimberSupplier also needs to consider the internal prerequisites to becoming proficient in regard to customer needs:

We need a more thorough approach to understand our range and pricing.

BM sales manager, TimberSupplier.

\section{DISCUSSION}

Determinants of power in the studied buyer-seller relationships can be associated with resource utility and market scarcity (cf. Pfeffer and Salancik, 1978). The buyers possess a high resource utility, as well as high market scarcity (Table 2). The capacity of the buyers to influence, by putting high requirements on suppliers and their offerings, and by putting pressure on their margins, is substantial. From this viewpoint, the buyer exercises coercive power, as they accomplish a change in both supplier behavior and profitability, although this is met with resistance (Emerson, 1962; French and Raven, 1968). 
Table 2: Balancing power in the buyer-supplier relationship

\begin{tabular}{|c|c|c|c|}
\hline Actor & Determinants of power & Ability to influence & $\begin{array}{l}\text { Dynamic change of } \\
\text { power position }\end{array}$ \\
\hline Supplier & $\begin{array}{l}\text { Low market scarcity: } \\
\text { 1) Many suppliers with } \\
\text { similar product offerings. } \\
\text { 2) Buyers can utilize } \\
\text { expertise from other } \\
\text { sources. } \\
\text { Low resource utility: } \\
\text { Supplier has a modest } \\
\text { supply of information } \\
\text { regarding costs and } \\
\text { demand for their } \\
\text { products. }\end{array}$ & Low ability. & $\begin{array}{l}\text { Higher market scarcity: } \\
\text { 1) Buyers are becoming } \\
\text { dependent on the } \\
\text { supplier's market } \\
\text { expertise. } \\
\text { 2) The supplier has } \\
\text { unexploited resources in } \\
\text { terms of the supply of } \\
\text { information and financial } \\
\text { resources. } \\
\text { Higher resource utility: } \\
\text { Buyer wishes for closer } \\
\text { collaboration and higher } \\
\text { supplier involvement } \\
\text { (more or less unresisted } \\
\text { change). }\end{array}$ \\
\hline Buyer & $\begin{array}{l}\text { High market scarcity: } \\
\text { Few large buyers. } \\
\text { High resource utility: } \\
\text { 1) Large purchasing clout } \\
\text { of buyer. } \\
\text { 2) Provides supplier } \\
\text { access to large market. }\end{array}$ & $\begin{array}{l}\text { High ability: } \\
\text { Buyer can place high } \\
\text { demands on supplier and } \\
\text { its offerings. } \\
\text { Buyer is able to put } \\
\text { pressure on the margins } \\
\text { of the supplier. }\end{array}$ & $\begin{array}{l}\text { Little or no change in } \\
\text { market scarcity and } \\
\text { resource utility situation. }\end{array}$ \\
\hline
\end{tabular}

The normal way of thinking about power is that it is good to possess it, and that an actor does not want to surrender its power position to another actor (e.g. Dahl, 1957; Ailawadi, 2001; Burt and Sparks, 2003). However, in this sector, BMs' have many components and products to manage, which means that they cannot fully focus on and have control over all their products and components. The BMs therefore want their suppliers to participate more in the management of their assortment.

The demands from the BMs placed on the timber supplier can be categorized as relating to information about products, regional and local demand, and finally the usage of the products. The timber supplier studied in this case has access to information about its products, and the differences in local and regional demand. This information can be used to improve the assortment management of the BMs.

As argued by Cox (2001) and Cox et al. (2003a), resource scarcity and utility can be a function of information asymmetry. In the studied case, the BMs are demanding that the supplier uses its understanding about products, regional and local demand, and the usage of its products. In other words, the BMs are urging the supplier to use this information asymmetry in the business dealings between the two parties. This also means that BMs are willing to allow, or even demanding, the wood supplier to provide services based on information about the BMs' operations and market. The supplier can subsequently increase its influence and control over certain areas in the BMs' operations, such as assortment management. 
In this case, general information relates to the issue of general product and technical knowledge as well as the usage of the products in different customer segments. Private information, on the other hand, is here more relationship specific, and deals with the assortment decisions for the BMs and the different branches. Although the supplier is equipped with this information, they have not previously utilized it to its full extent. Based on the demands from the BMs, this provides a way to improve the information asymmetry for the supplier, and thus furthers the control of the assortment in the marketing channel. This issue-specific control given to the supplier shifts the power balance in favor of the supplier. This happens without resistance on the BMs' part, since it improves efficiency in the marketing channel, and as a result the BMs are able to improve their customer offer. With changes in the power position caused by the exercise of information asymmetry in a noncoercive manner, the determinants of power in the buyer-supplier relationship change. Figure 3 and Table 2 illustrate the dynamic change of power position.

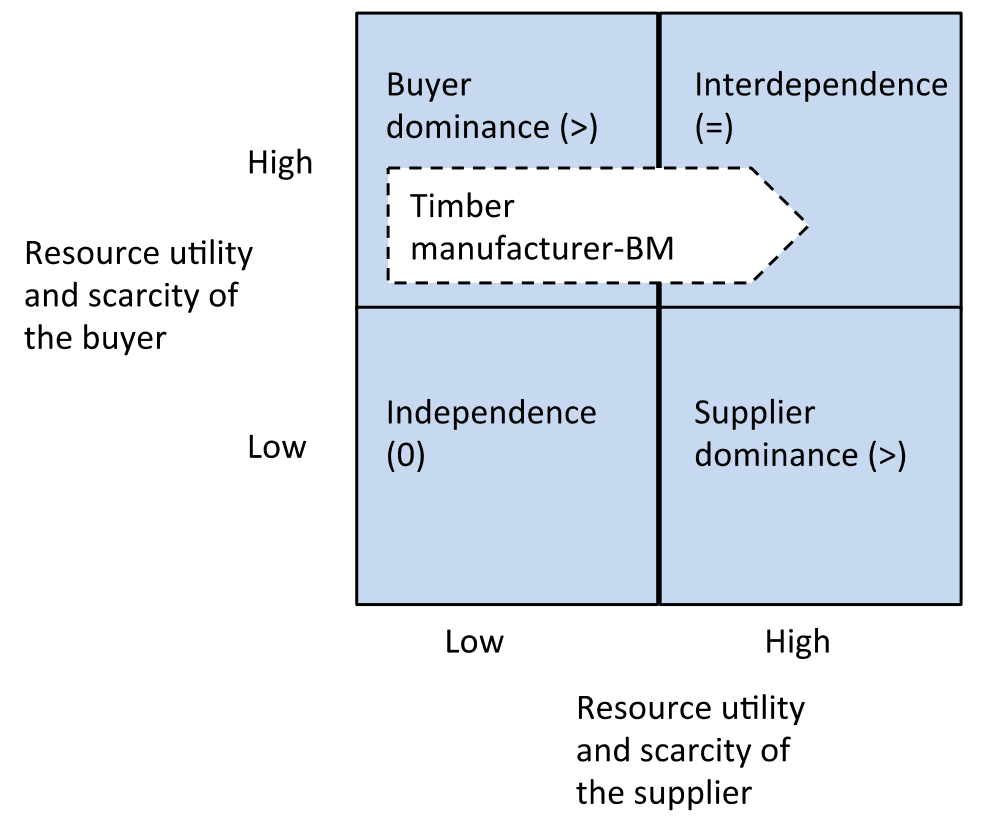

Figure 3: Moving the relationship from buyer-dominance to interdependence (adapted from Chicksand, 2009)

A balanced power position often leads to long-term collaborative relationships (Chicksand, 2009). Therefore, when the relationship moves from buyer dominance to more interdependence, the collaboration between the actors is likely to increase. If there is a balanced power position in the alliance, and both parties are aware of this situation, the sharing of risks and rewards from the relationship are more likely to be balanced (cf. Chicksand, 2009). Furthermore, we argue that the power situation can change over time, depending on the measures taken by the buyer and seller. In this case, even though the buyer and supplier are moving to become more interdependent, the total power balance is still in favor of the buyer (see Figure 3).

In the long term, the question is whether or not this power change will result in a shift in financial performance or in a higher degree of customer retention in favor of the supplier (cf. Kurtuluş and Nakkas, 2011). In the short term, this risk is relatively small since the existing offers from competing suppliers are still substitutable. This is more than likely also the reason why BMs are willing to invite the supplier to shoulder more control and influence on the assortment and on the supply chain. 


\section{CONCLUSIONS}

In this paper, we studied a buyer-seller relationship in the context of low-margin products. This contributes to the industrial marketing research literature by adding to the understanding of how supplier strategies can affect the degree of dependence, and alter the power position. As a result of this study, we claim that information asymmetry is a power resource that can alter the power position of two parties over time.

Some researchers, for instance Cox $(1999 ; 2001 ; 2007)$, have argued that information asymmetry is a power resource. This power resource can be regarded as the ability of one party to subjectively understand their own economic interests and those of their exchange parties. However, because of information asymmetry, predetermined contracts are difficult to achieve since, in some circumstances, buyers and sellers are just not aware of what they do not know. This is a particular problem when one party has more information than the other, both before and after contracts are signed (Cox, 2007).

In this case, the information asymmetry consists of the understanding of 1) products, 2) regional and local demand, and 3) the usage of the products. This paper conjectures that using non-coercive power bases, chiefly based on information asymmetry regarding products and regional demand, can change the power balance in a buyer-supplier relationship (cf. Kurtulus and Toktay, 2005; Kurtulus and Toktay, 2007). This information asymmetry becomes a resource, with both high utility and scarcity. When the power balance changes (the relative dependence), the ability of the two actors to use coercive power is also affected.

In contrast to relationship management literature (Morgan and Hunt, 1994), this study not only focuses on trust and commitment in business relationships, but also stresses the relevance of considering actions intended to change the power balance. As this study specifically focuses on a move from buyer dominance toward interdependence (cf. Cox, 1999), it shows how theories on power can be applied to motivate a development toward a more collaborative relationship. Thus, a better understanding of power imbalances in relationships between buyers and suppliers could foster greater collaboration. This conclusion is in accordance with Hingley's (2005) statement that power-imbalanced relationships are prevalent and important to study.

\subsection{Managerial implications}

The findings of this paper suggest that a possible way of balancing power in the supplierretailer relationship is the use of non-coercive power resources. In this study, non-coercive power is exercised through the provision of supplementary services, which increase efficiency in the distribution channel and thus enable a lower price to end-customers. In this way, a supplier develops its services rather than its physical products in order to balance power. The end-customers' requirements for suitable products are mainly limited to price and quality. Therefore, a differentiation in terms of innovative products would, if anything, impair the offering, as the prices would likely increase without any substantial increase in either quality or usability.

Also, in line with Woodruff (1997), both the supplier and the retailer are required to understand how the offering of the supplier helps achieve the goals and purposes of the retailer. If the retailer delegates some of its activities and responsibilities to a supplier, the retailer must see the benefit in doing so. In some of their comments, BM branch managers noted that the supplier did not understand the unique situation of the specific BM branch, so was not able to help, for example, in developing their assortment. Regardless of the accuracy of this claim, the BM branch managers do not see how the suppliers can help them achieve 
their goals, so are not interested in balancing power between the actors. The supplier, on the other hand, must be aware of how a new offering affects the goals and purposes of the BM. As mentioned in the results, BMs can encourage their suppliers to bring an interesting offering to the table, indicating that the suppliers need to explain how their offerings create value and achieve the BMs' goals and purposes.

The supplementary services offered in this case require an integration of the supplier in certain activities and responsibilities traditionally performed by the retailer. For this to be beneficial for the supplier-retailer dyad, the supplier must possess resources that make it better suited to performing these activities and taking on these new responsibilities (Das and Teng, 2000). Literature on resource complementarity suggests that, by combining the resources of the firms in an alliance, performance can be improved (Harrison et al., 2001; Lin et al., 2009). The results in this paper indicate a need to also consider the power balance between the actors in an alliance. Depending on the changes made to the way in which a firm's resources are utilized, the improvements, in terms of higher performance, can benefit the two actors to differing extents.

\section{REFERENCES}

Agapiou, A., Flanagan, R., Norman, G. \& Notman, D. (1998). The Changing Role of Builders Merchants in the Construction Supply Chain. Construction Management and Economics, 16 (3), 351-361

Aiken, M. \& Hage, J. (1968). Organizational Interdependence and Intra-Organizational Structure. American Sociological Review, 33 (6), 912-930

Ailawadi, K. L. (2001). The Retail Power-Performance Conundrum: What Have We Learned? Journal of Retailing, 77 (3), 299-318

Ailawadi, K. L., Borin, N. \& Farris, P. W. (1995). Market Power and Performance: A CrossIndustry Analysis of Manufacturers and Retailers. Journal of Retailing, 71 (3), 211-248

Akerlof, G. A. (1970). The Market for 'Lemons': Quality Uncertainty and the Market Mechanism. Aug, 84 (3), 488-500

Bacharach, S. B. \& Lawler, E. J. (1986). Power Dependence and Power Paradoxes in Bargaining. Negotiation Journal, 2 (2), 167-174

Barratt, M. \& Oliveira, A. (2001). Exploring the Experiences of Collaborative Planning Initiatives. International Journal of Physical Distribution \& Logistics Management, 31 (4), 266-289

Blau, P. M. (1964). Exchange and Power in Social Life. Transaction Publishers

Bloom, P. N., Gundlach, G. T. \& Cannon, J. P. (2000). Slotting Allowances and Fees: Schools of Thought and the Views of Practicing Managers. Journal of Marketing, 64 (2), 92108

Bowles, S. \& Gintis, H. (1993). The Revenge of Homo Economicus: Contested Exchange and the Revival of Political Economy. The Journal of Economic Perspectives, 7 (1), 83-102

Brown, J. R., Lusch, R. F. \& Muehling, D. D. (1983). Conflict and Power-Dependence Relations in Retailer-Supplier Channels. Journal of Retailing, 59 (4), 53

Burt, S. L. \& Sparks, L. (2003). Power and Competition in the Uk Retail Grocery Market. British Journal of Management, 14 (3), 237-254

Campbell, N. C. \& Cunningham, M. T. (1983). Customer Analysis for Strategy Development in Industrial Markets. Strategic Management Journal, 4 (4), 369-380

Caniëls, M. C. \& Gelderman, C. J. (2007). Power and Interdependence in Buyer Supplier Relationships: A Purchasing Portfolio Approach. Industrial Marketing Management, 36 (2), 219-229 
Chicksand, D. (2009), Creating a Sustainable Uk Farming and Food Industry: An Analysis of Partnership Thinking as a Solution to the Problems in the Uk Farming and Food Industry. Doctoral Theses, University of Birmingham

Collins, A. (2002). The Determinants of Retailers' Margin Related Bargaining Power: Evidence from the Irish Food Manufacturing Industry. International Review of Retail, Distribution \& Consumer Research, 12 (2), 165-189

Cook, K. \& Henderson, J. (1998). Power and Firm Profitability in Supply Chains: French Manufacturing Industry in 1993. Strategic Management Journal, 19 (10), 909-926

Cook, K. S. (1977). Exchange and Power in Networks of Interorganizational Relations*. The Sociological Quarterly, 18 (1), 62-82

Cook, K. S. \& Emerson, R. M. (1978). Power, Equity and Commitment in Exchange Networks. American Sociological Review, 43 (5), 721-739

Cox, A. (1999). Power, Value and Supply Chain Management. Supply Chain Management: An International Journal, 4 (4), 167-175

Cox, A. (2001). The Power Perspective in Procurement and Supply Management. Journal of Supply Chain Management, 37 (2), 4-7

Cox, A. (2007). Transactions, Power and Contested Exchange: Towards a Theory of Exchange in Business Relationships. International Journal of Procurement Management, 1 (1), 38-59

Cox, A. \& Chicksand, D. (2007). Are Win-Wins Feasible? Power Relationships in Agri-Food Supply Chains and Markets. In D. Burch and G. Lawrence (Eds.), Supermarkets and AgriFood Supply Chains: Transformations in the Production and Consumption of Foods (pp. 7499). Cheltenham, U.K. and Northampton, Mass.: Elgar

Cox, A., Ireland, P., Lonsdale, C., Sanderson, J. \& Watson, G. (2003a). Supply Chains, Markets and Power: Managing Buyer and Supplier Power Regimes. SUNY Press

Cox, A., Lonsdale, C., Watson, G. \& Qiao, H. (2003b). Supplier Relationship Management: A Framework for Understanding Managerial Capacity and Constraints. European Business Journal, 15 (3), 135-145

Cox, A., Sanderson, J. \& Watson, G. (2000). Power Regimes: Mapping the DNA of Business and Supply Chain Relationship. Stratford-upon-Avon: Earlsgate press

Cox, A., Watson, G., Lonsdale, C. \& Sanderson, J. (2004). Managing Appropriately in Power Regimes: Relationship and Performance Management in 12 Supply Chain Cases. Supply Chain Management, 9 (5), 357-371

Dahl, R. A. (1957). The Concept of Power. Behavioral Science, 2 (3), 201-215

Das, T. K. \& Teng, B.-S. (2000). A Resource-Based Theory of Strategic Alliances. Journal of Management, 26 (1), 31-62

Dubois, A. \& Gadde, L.-E. (2002). Systematic Combining: An Abductive Approach to Case Research. Journal of Business Research, 55 (7), 553-560

Dussart, C. (1998). Category Management:: Strengths, Limits and Developments. European Management Journal, 16 (1), 50-62

Easton, G. (2010). Critical Realism in Case Study Research. Industrial Marketing Management, 39 (1), 118-128

Eisenhardt, K. M. (1989). Building Theories from Case Study Research. The Academy of Management Review, 14 (4), 532-550

Eisenhart, K. M. \& Graebner, M. E. (2007). Theory Building from Cases: Opportunities and Challenges. Academy of Management Journal, 50 (1), 25-32

El-Ansary, A. I. \& Stern, L. W. (1972). Power Measurement in the Distribution Channel. Journal of Marketing Research, 9 (1), 47-52 
Ellström, D. (2013), Proactive Range Management - a Timber Supplier's Efforts to Influence the Product Assortment of Builders' Merchants. Licentiate Thesis, Department of Management and Engineering, Linköping University

Emerson, R. M. (1962). Power-Dependence Relations. American Sociological Review, 27 (1), 31-41

Etgar, M. (1976). Channel Domination and Countervailing Power in Distributive Channels. Journal of Marketing Research, 13 (3), 254-262

Farris, P. W. \& Ailawadi, K. L. (1992). Retail Power: Monster or Mouse? Journal of Retailing, 68 (4), 351-369

Foros, Ø. \& Jarle Kind, H. (2008). Do Slotting Allowances Harm Retail Competition?*. The Scandinavian Journal of Economics, 110 (2), 367-384

Foros, Ø., Kind, H. J. \& Sand, J. Y. (2009). Slotting Allowances and Manufacturers' Retail Sales Effort. Southern Economic Journal, 76 (1), 266-282

Frazier, G. L. \& Antia, K. D. (1995). Exchange Relationships and Interfirm Power in Channels of Distribution. Journal of the Academy of Marketing Science, 23 (4), 321-326

French, J. \& Raven, B. H. (1968). The Bases of Social Power. In D. Cartwright and A. F. Zander (Eds.), Group Dynamics: Research and Theory (pp. 259-270). New York, NY: Harper \& Row

Galbraith, C. S. \& Stiles, C. H. (1983). Firm Profitability and Relative Firm Power. Strategic Management Journal, 4 (3), 237-249

Gaski, J. F. (1984). The Theory of Power and Conflict in Channels of Distribution. Journal of Marketing, 48 (3), 9-29

Guan, W. (2013), The Role of Suppliers and Retailers - Cases of Timber Product Distribution Channels. Doctoral Thesis, Department of Management and Engineering, Linköping University

Harris, B. \& McPartland, M. (1993). Category Management Defined: What It Is and Why It Works. Progressive Grocer, 72 (9), 5

Harrison, J. S., Hitt, M. A., Hoskisson, R. E. \& Ireland, R. D. (2001). Resource Complementarity in Business Combinations: Extending the Logic to Organizational Alliances. Journal of Management, 27 (6), 679-690

Hartley, J. (2004). Case Study Research. Essential guide to qualitative methods in organizational research,

Henningsson, M. (2005), Retail Trade Demands on Distributors - Strategic and Operational Implications. Lecientiate thesis, International Graduate School of Management and Industrial Engineering, Linköping University

Hingley, M. K. (2005). Power to All Our Friends? Living with Imbalance in SupplierRetailer Relationships. Industrial Marketing Management, 34 (8), 848-858

Hunt, S. D. \& Nevin, J. R. (1974). Power in a Channel of Distribution: Sources and Consequences. Journal of Marketing Research, 11 (2), 186-193

Justensen, L. \& Mik-Meyer, N. (2011). Kvalitativa Metoder - Från Vetenskap Till Praktik. Lund: Studentlitteratur

Kaplan, A. (1964). Consequences and Prospects. Kahn, R. and Boulding, E.: Power and Conflict in Organizations. London, Tavistock Publications,

Kracklauer, A., Passenheim, O. \& Seifert, D. (2001). Mutual Customer Approach: How Industry and Trade Are Executing Collaborative Customer Relationship Management. International Journal of Retail \& Distribution Management, 29 (12), 515-519

Kurtuluş, M. \& Nakkas, A. (2011). Retail Assortment Planning under Category Captainship. Manufacturing \& Service Operations Management, 13 (1), 124-142

Kurtulus, M. \& Toktay, B. (2005). Category Captainship: Who Wins Who Loses? Available at SSRN 934970, 
Kurtulus, M. \& Toktay, B. (2007), Category Captainship: Outsourcing Retail Category Management. Vanderbilt University - Operations Management, January 2007

Leonidou, L. C., Talias, M. A. \& Leonidou, C. N. (2008). Exercised Power as a Driver of Trust and Commitment in Cross-Border Industrial Buyer-Seller Relationships. Industrial Marketing Management, 37 (1), 92-103

Lin, Z., Yang, H. \& Arya, B. (2009). Alliance Partners and Firm Performance: Resource Complementarity and Status Association. Strategic Management Journal, 30 (9), 921-940

Lindblom, A. \& Olkkonen, R. (2006). Category Management Tactics: An Analysis of Manufacturers' Control. International Journal of Retail \& Distribution Management, 34 (6), $482-496$

Lonsdale, C. (2005). Contractual Uncertainty, Power and Public Contracting. Journal of Public Policy, 25 (2), 219

Lusch, R. F. \& Brown, J. R. (1982). A Modified Model of Power in the Marketing Channel. Journal of Marketing Research, 19 (3), 312-323

Lusch, R. F. \& Ross, R. H. (1985). The Nature of Power in a Marketing Channel. Journal of the Academy of Marketing Science, 13 (3), 39-56

Meredith, J. (1998). Building Operations Management Theory through Case and Field Research. Journal of Operations Management, 16 (4), 441-454

Messinger, P. R. \& Narasimhan, C. (1995). Has Power Shifted in the Grocery Channel? Marketing Science, 14 (2), 189-223

Meyer, C. B. (2001). A Case in Case Study Methodology. Field methods, 13 (4), 329-352

Miles, M. B. \& Huberman, A. M. (1984). Qualitative Data Analysis: A Sourcebook of New Methods. Beverly Hills: Sage Publications

Morgan, R. M. \& Hunt, S. D. (1994). The Commitment-Trust Theory of Relationship Marketing. Journal of Marketing, 58 (3), 20-38

Nord, T. (2005), Structure and Developments in the Solid Wood Value Chain: Dominant Saw Milling Strategies and Industrialized Housing. Samhällsbyggnad/träbyggnad, Luleå Tekniska Universitet

Pfeffer, J. \& Salancik, G. (1978). The External Control of Organizations: A Resource Dependence Perspective. New York, NY: Harper and Row

Piekkari, R., Plakoyiannaki, E. \& Welch, C. (2010). 'Good' Case Research in Industrial Marketing: Insights from Research Practice. Industrial Marketing Management, 39 (1), 109117

Porter, M. E. (1980). Competitive Strategy : Techniques for Analyzing Industries and Competitors. New York, NY: Free Press

Provan, K. G. \& Gassenheimer, J. B. (1994). Supplier Commitment in Relational Contract Exchanges with Buyers: A Study of Interorganizational Dependence and Exercised Power*. Journal of Management Studies, 31 (1), 55-68

Ramsay, J. (1994). Purchasing Power. European Journal of Purchasing and Supply Management, 1 (3), 125-138

Rehme, J., Nordigården, D., Brege, S. \& Chicksand, D. (2013). Outsourcing to a NonDeveloped Supplier Market: The Importance of Operational Aspects in Outsourcing. Journal of Purchasing and Supply Management, 19 (4), 227-237

Saunders, M., Lewis, P. \& Thornhill, A. (2007). Research Methods for Business Students. (4th Edition). Harlow: Prentice Hall

Savage, J. (2000). Participative Observation: Standing in the Shoes of Others? Qualitative Health Research, 10 (3), 324-339

Shaffer, G. (2005). Slotting Allowances and Optimal Product Variety. Advances in Economic Analysis \& Policy, 5 (1), 
Subramanian, U., Raju, J. S., Dhar, S. K. \& Wang, Y. (2010). Competitive Consequences of Using a Category Captain. Management Science, 56 (10), 1739-1765

Sudhir, K. \& Rao, V. R. (2006). Do Slotting Allowances Enhance Efficiency or Hinder Competition? Journal of Marketing Research, 43 (2), 137-155

Sullivan, M. W. (1997). Slotting Allowances and the Market for New Products. The Journal of Law and Economics, 40 (2), 461-494

Teece, D. J. (1986). Profiting from Technological Innovation: Implications for Integration, Collaboration, Licensing and Public Policy. Research policy, 15 (6), 285-305

Van de Ven, A. H. \& Walker, G. (1984). The Dynamics of Interorganizational Coordination. Administrative Science Quarterly, 598-621

Wilkinson, I. \& Kipnis, D. (1978). Interfirm Use of Power. Journal of Applied Psychology, 63 (3), 315-320

Wilkinson, I. F. (1996). Distribution Channel Management: Power Considerations. International Journal of Physical Distribution \& Logistics Management, 26 (5), 31-41

Woodruff, R. (1997). Customer Value: The Next Source for Competitive Advantage. Journal of the Academy of Marketing Science, 25 (2), 139-153

Yin, R. K. (2009). Case Study Research: Design and Methods. (Fourth Edition). London: Sage Publication 